University of Nebraska - Lincoln

DigitalCommons@University of Nebraska - Lincoln

December 1998

\title{
The Race Race in Black and White: The 1995 Louisiana Gubernatorial Election
}

Byron D. Orey

borey2@unl.edu

Follow this and additional works at: https://digitalcommons.unl.edu/poliscifacpub

Part of the Political Science Commons

Orey, Byron D., "The Race Race in Black and White: The 1995 Louisiana Gubernatorial Election" (1998). Faculty Publications: Political Science. 17.

https://digitalcommons.unl.edu/poliscifacpub/17

This Article is brought to you for free and open access by the Political Science, Department of at DigitalCommons@University of Nebraska - Lincoln. It has been accepted for inclusion in Faculty Publications: Political Science by an authorized administrator of DigitalCommons@University of Nebraska - Lincoln. 


\title{
THE RACE RACE IN BLACK AND WHITE: THE 1995 LOUISIANA GUBERNATORIAL ELECTION
}

\author{
Byron D'Andra Orey \\ University of New Orleans
}

This analysis marks the first time that the black threat thesis posited in 1949 by $V . O$. Key, Jr. has been examined by employing a black versus white head-to-head election. This study tests the black threat thesis in the 1995 Louisiana gubernatorial runoff election. The unit of analysis is the parish (same as county) and the primary data sources used in this analysis include election returns by parish, turnout data by race by parish and demographic and socio-economic variables for parishes taken from the United States Census. The findings are consistent with Key's black threat hypothesis. White support for the racially conservative white candidate is positively and significantly associated with the level of black density.

$\mathbf{I}_{\mathrm{n}}$

head-to-head elections involving a black and a white candidate, patterns of racially polarized voting have persisted (Huckfeldt and Kohfeld 1989; Loewen 1990; Kleppner 1985; Kohfeld and Sprague 1992; Jeffries 1995). However, one of the lingering questions associated with this phenomenon is whether racial polarization increases or decreases, depending upon the increase in the black population. Przeworski, in explaining contextual models, states "The behavior in individuals depends not only upon their own characteristics but also upon the characteristics of other persons within the same social environment" $(1974,29)$. Further, in a seminal piece, Key (1949) posited that southern whites participated in politics at higher rates as the concentration of black population increased. Key coined this phenomenon as "black threat."

This study tests the "black threat" thesis in the 1995 Louisiana gubernatorial runoff election featuring an African American candidate, Cleo Fields, and a white candidate, Mike Foster. The analysis follows the lead of those scholars investigating contextual effects of vote choice by whites (Key 1989; Wright 1977; Giles and Buckner 1993, 1996). However, the research here contributes to the extant literature by examining a white versus black contest. The state of Louisiana is a particularly interesting case because its electorate has traditionally voted a straight Democratic 
ticket. Indeed, Erickson, Wright, and Mclver (1993) illustrate that in terms of average partisan support between 1976-1988, Louisiana was the most Democratic state in the nation.

According to Huckfeldt and Sprague, "white racial hostility is a common feature of American political life, and it frequently varies as a direct function of blacks' presence in the population" $(1993,284)$. One manifestation of this approach has been Key's (1949) "black threat" hypothesis. As stated above, the purpose of this research is to examine the "black threat" hypothesis within the context of the 1995 Louisiana gubernatorial runoff election, a head-to-head contest between a black candidate and a white candidate. This analysis will first provide a brief discussion of contextual effects and the "black threat" hypothesis. Second, this paper will provide a discussion of the 1995 Louisiana gubernatorial contest. Third, there will be a detailed presentation of the data and methods. Finally, there will be a discussion of the findings, followed by a brief conclusion.

\section{BLACK DENSITY AND VOTE CHOICE}

While many of the pioneering voting studies recognized the importance of the local context in shaping electoral behavior (Lazarsfeld, Berelson, and Gaudet 1968), analyzing contextual effects has been a largely neglected area of political science inquiry. However, there has been a noticeable increase in the attention accorded the contextual dimension (Giles and Buckner 1993, 1995; Huckfeldt and Sprague 1993; Huckfeldt 1986; Carsey 1995). Many of the studies examining contextual effects, as they relate to political participation (e.g., registration and voting behavior), have categorized this behavior as occurring within the context of conflict or assimilation. Said differently, this paradox could work in one of two ways: white support for the black candidate could increase with percent black population (social contract theory) or it could decrease as black population increases (black threat theory).

Lazarsfeld, et al. state, "Voting is essentially a group experience. People who work or live or play together are likely to vote for the same candidate" $(1968,137)$. In a more recent study, Carsey (1995) finds support for the racial harmony or assimilation thesis. He shows that in 1989, as the black population in precincts in New York City increased, whites were more likely to support the black mayoral candidate.

In contrast to racial harmony, the extant literature has found a relatively strong relationship between black population density and racial conflict. As stated previously, Key (1949) has coined this phenomenon "black threat." Wright (1977) provides support for Key's "black threat" thesis in an analysis assessing the white vote for Wallace in the 1968 presidential election. The author provides evidence which suggests that southern rural whites living in counties with high black densities were more likely to support George Wallace in the 1968 presidential election. Giles and Buckner (1993) explain the white vote for David Duke across parishes in Louisiana in the 1990 United States Senate race as being a function of racial (black) density and other socio-economic variables. Further, the authors (Giles and Buckner 1995) extend this work by adding the 1988 presidential election and the 1991 Louisiana gubernatorial primary and runoff elections. The inclusion of the 1988 Bush/Dukakis presidential election allows for an assessment of the electorate's response to the racial undertones inherent in Bush's campaign. One notable example of this was the Willie Horton advertisement.

In one of the most recent exchanges regarding the racial threat hypothesis, Voss (1996) introduces a number of methodological concerns regarding the work of Giles and Buckner $(1993,1995)$. In particular, Voss contends that the authors failed to weight their data. Said differently, given that they employ ordinary least squares (OLS), Voss indicates that the authors should have weighted their data to avoid violating the assumption of heteroscedasticy. Using Generalized Least Squares, Voss (1996) provides a remedy to the authors' problem. Further, Voss argues that Giles and Buckner misspecified their model by excluding an interaction (or a multiplicative term) which would capture the percentage of blacks in an urban area. Once Voss controls for this interaction and applies GLS, he concludes that the racial threat hypotheses "fails."

\section{THE LOUISIANA GUBERNATORIAL RUNOFF}

Whereas the current literature is limited to the examination of white versus white contests, this study extends this literature by taking an additional step to investigate a black-white contest. More specifically, this study examines the Cleo. Fields and Mike Foster 1995 Louisiana gubernatorial runoff. It is expected that as the black population percentage in a parish increases, the percentage of the white vote for Foster will increase.

The 1995 Fields versus Foster election featured a conservative white candidate, Mike Foster, and a liberal African American candidate, Cleo Fields. As a United States Congressman, Fields voted more than $90 \%$ of the time with the Democratic party and served as an advocate for social welfare programs (Alpert 1995). Based on an assessment of the congressman's voting record and his views, the New Orleans Times Picayune labeled him as a liberal. Such perceptions aided in the marginalization of Fields' support from th s white community. 
On the other hand, prior to qualifying for the gubernatorial primary, Foster converted from the Democratic party to the Republican party and made stronger appeals to the white electorate. This conversion increased his self-proclaimed image as a conservative. Foster's campaign included a call to repeal affirmative action, support for the plaintiffs in the Hays $v$. Louisiana (1994) case challenging Fields' majority African American congressional district, and opposition to the motor voter law, all of which have potential negative repercussions for the African American community. Last, Foster refused to repudiate the endorsement he received from former neo-Nazi and white supremacist David Duke. Hence, it is not surprising that an exit poll sponsored by the Times Picayune found that only about four percent of African American voters supported Foste 1995).

Although the 1995 Louisiana gubernatorial election campaign did not entail the overt racism present during Key's (1949) research, there were detections of racially coded language used by Foster. According to Edsall and Edsall (1991), racial code words have hidden meanings-they are implicitly race-laden. One example of Foster's use of racially coded language is his statement that predominately white Jefferson Parish "is right next to the jungle in New Orleans and it has a very low crime rate" (Ott $1995,3)$. To confirm the hypothesis proposed in this paper, the findings should reveal that as the percentage of black population in a parish increases, the percentage of the white vote for Foster should increase, holding all other variables constant.

\section{DATA AND METHODS}

The unit of analysis is the parish (the name for counties in Louisiana). Given the use of aggregate level data, we must acknowledge that we are confronting the "ecological fallacy"- the possibility of making false inferences about individuals from aggregate data. However, Giles and Buckner (1993) contend that since past research has provided documentation of a linkage between racial density at the parish level and individual perceptions of threat, we should be less concerned about the problem of cross-level inference in this context. ${ }^{1}$

The data consist of election returns by parish, turnout data by race by parish, and demographic and socio-economic variables for parishes derived from the United States Census. The dependent variable, the percentage of the white vote in each parish that was cast for Foster, is operationalized as the total vote cast for Foster (by parish) divided by total white sign-in, by parish. ${ }^{2}$ This analysis makes the assumption that the black votes acquired by Foster, whether advertent or inadvertent, are insufficient to affect the results. In fact, the Times Picaynne estimated Foster as receiving only four percent of the African American vote. Based on this evidence it is assumed that the vote for Foster was uniracially white.

The contextual variable of interest, black density, is measured as the - percentage of a parish's population categorized as black. Although the primary interest of this analysis is the impact of the racial density of blacks on the percentage of the white vote for Foster, other control variables have been included to fully specify the model.

Abrahamson (1980) suggests that urban areas tend to be more tolerant in racial affairs. Therefore a variable tapping the urban population is operationalized as the percentage of urban population in each of the parisites. $^{3}$ As stated previously, Voss (1996) employs an interaction term between black density and urban population. The author also finds support for a variable tapping the percentage of French speaking residents in each parish. Thus, in staying consistent with the models introduced in the 1996 exchange (Voss 1996; Giles and Buckner 1996), the percentage Urban X Black Density and the percent French speaking residents is included in this model.

Giles and Evans (1985) contend that whites with a high school education perceive large concentrations of blacks as a threat. Hence, this paper employs the percentage of the white population with a high school degree as an explanatory variable. Previous literature (Giles and Evans 1985; Kinder and Sanders 1996) has also employed income as an explanation for vote choice. This variable is presented here as the white median income of each parish as reported by the United States Bureau of the Census.

Giles and Buckner (1993) postulate that those whites who are unemployed will vote for the racially conservative candidate as a protest against economic bad times. They found that as the percentage of unemployed voting age whites increased in a parish, the vote for Duke increased. Based on these findings, it is posited that because of such programs as affirmative action, unemployed whites would perceive blacks as a greater threat and therefore would be more supportive of Foster's campaign to repeal affirmative action. This variable is simply the percentage of whites who are unemployed in each parish.

Additionally, it is expected that people who were socialized outside of the southern region will be less supportive of a traditional "old" South candidate (Giles and Buckner 1993). This variable is measured as the percent of the white population born outside of the South.

Finally, Giles and Buckner (1993) use the percentage of whites turning 18 after 1961 as a threshold for those individuals socialized during and after the era that succeeded the resistant southern era. In other words, because 
some of these individuals were socialized during the time that the Civil Rights Act of 1964 and the Voting Rights Act of 1965 were passed, and some were socialized after this period (but none before it), it is expected that these voters would be more tolerant in their vote choice.

The method employed in this analysis is multiple regression analysis. However, given that the population of each parish varies significantly, Generalized Least Squares is employed to control for the problem of heteroscedasticity. ${ }^{4}$ The dependent variable, percent white vote for Foster, is regressed on the independent variables identified above.

\section{FINDINGS}

The effect of black density (by parish), and the independent variables describing the white support for Foster are presented in Table 1. Consistent with Key's black threat hypothesis, white support for Foster is positively and significantly associated with the level of black concentration.

Table 1 provides two models, Model A and Model B. Model A provides regression results without the interaction term (\% Urban X Black Density)

Table 1

Percentage White Vote for Foster Employing Generalized Least Squares

\begin{tabular}{lccccc}
\hline & \multicolumn{2}{c}{ Model A } & & \multicolumn{2}{c}{ Model B } \\
\cline { 2 - 3 } \cline { 5 - 6 } \multicolumn{1}{c}{ Variables } & $\mathrm{B}$ & SE B & & $\mathrm{B}$ & SE B \\
\hline PFRENCH & -.03 & .02 & & -.01 & .02 \\
PBLACK & $.13^{* *}$ & .04 & & $.18^{* *}$ & .05 \\
PBURBAN & - & $-.003^{* * *}$ & .000 \\
PHSEDUC & -.27 & .14 & & -.21 & .13 \\
PMIGRATE & -.12 & .08 & & -.08 & .08 \\
PUNEMPLO & $.82^{*}$ & .38 & & $.87^{*}$ & .39 \\
PURBAN & -.00 & .02 & & $.07^{* *}$ & .03 \\
PYOUNG & -.03 & .02 & & -.04 & .03 \\
INCOME & -.00 & .00 & & .00 & .00 \\
\multicolumn{1}{c}{ Constant } & $88.85^{* *}$ & 8.26 & & $79.48^{* *}$ & 9.10
\end{tabular}

PFRENCH $=\%$ French speaking population

PBLACK $=\%$ Black population

PBURAN $=$ Interaction between \%urban and \%Black density

PHSEDUC $=\%$ with a high school degree

PMIGRATE $=\%$ white migration

PUNEMPLO $=\%$ unemployed

PURBAN $=\%$ urban population

PYOUNG $=\%$ young

INCOME $=$ white per capita income

The traditional goodness of fit tests usually reported with OLS are not useful with GLS. and Model B reports the results with the interaction term included. In both models the Black Density variable is statistically significant and in the posited direction. However, the magnitude increases from .13 in Model A to approximately .18 in Model B. Furthermore, the inclusion of the interaction term in Model B changes the magnitude of the urban variable from 0 to .07. Given the performance of Model B the results for this model will be discussed later.

Based on Model B the regression coefficient obtained for the black density variable is .18 , ceteris paribus. In interpreting this coefficient we can say that as the percentage of blacks increases by $1 \%$, the white vote for Foster increases by $.18 \%$. Further, a $10 \%$ increase in the black population increases the white vote for Foster by $1.8 \%$. A $30 \%$ increase in black population increases the Foster voter by 5.4, and so on. Given that the largest percentage of blacks in a parish was $64 \%$, we can infer that roughly $11.52 \%$ of the white vote went to Foster based on Key's hypothesis.

In addition to the black density coefficient, both the urban coefficient (PURBAN) and the interaction term (PBURBAN) are highly significant at the .01 level. The results obtained by the urban coefficient confirm the presence of racial threat among whites living in urban areas. However, the interaction term sheds light on exactly which whites voted for Foster. Based on the results achieved for this variable we can infer that whites in urban settings with high concentrations of blacks were less likely to vote for Foster than whites in non-urban settings with high concentrations of blacks. Such findings do not negate the presence of racial threat. It simply means that the relationship is weaker in urban areas. What is important here is that the unit of analysis is the county. As stated above, Carsey (1995) reports that whites in New York City who lived in precincts with high concentrations of blacks were more inclined to vote for the black candidate than those whites living in areas with small black populations.

The work of Kinder and Sanders (1996) can also assist us in better understi. ting the interaction term. They find that the perception of personal racial threat is largely unconnected to actual circumstance but is closely related to feelings of racial hostility, or in their words racial resentment. According to the authors, the perception of racial threat is predicted best by the resentment whites feel toward blacks. Hence, it could be the case that because whites in the urban centers with high densities of blacks are less likely to feel racial hostility, they are less inclined to judge a candidate based on his or her race. On the other hand, rural and suburban whites are more affected by the percentage blacks in their parish because they are more likely to have racial hostility in the first place. 
Kinder and Sanders (1996) argue that whites make their judgments of blacks based on their perception of the threat that blacks might pose on whites as a group, rather than the threat blacks may pose on their personal welfare. Such a perception is more likely to affect those whites who do not live in close proximity to blacks. In sum, for Kinder and Sanders racial threat is a function of, not necessarily actual conditions of competition and conflict, but of the resentment that whites feel toward blacks.

Moreover, Key's (1949) racial threat hypothesis is not limited to residential propinquity. For sure, Key hypothesized racial threat to occur in the black belt states where whites had much more to lose (i.e., politically and economically). However, Key also makes the argument that whites in the hills of Mississippi perceived blacks to be a greater threat compared to whites in the Mississippi delta. One example given by Key is the support of plantation owners in the Mississippi delta for a better quality of life for blacks. According to Key,

...the delta encounters resistance from the hills to its proposals on the grounds that the planters promote the cause of the blacks. And for self-interest, if for no other, the planters must speak for their Negroes in such programs as health and education $(1949,235)$.

This ignited a greater degree of hostility for whites in the hills, for they were in direct competition with Negroes. The point here is that the greatest threat within the state was not based on residential propinquity, given that the majority of blacks lived in the delta and those whites most resentful of blacks resided in the hills.

\section{CONCLUSION}

Almost fifty years ago V. O. Key posited a positive relationship between the size of the black population and white resentment toward blacks. The analysis conducted here examining the 1995 Louisiana gubernatorial election, featuring a white conservative candidate, Mike Foster, and an African American liberal candidate, Cleo Fields, yields continuing support for Key's hypothesis, with a caveat.

Although the white candidate in this analysis was not perceived to be a racist, he did convey rhetoric to the electorate that can be categorized within the realm of subtle racism. The results obtained in this analysis are consistent with the findings of prior research examining the support of Louisiana voters for a racially conservative candidate. However, the research conducted here marks the first time that Key's hypothesis has been tested employing an African American candidate and a white candidate in a head-to-head contest. Thus the findings here accentuate past findings yielding support for Key's racial threat hypothesis.

Based on the findings reported here, by including an interaction between percent urban and percent black density we can infer that those whites residing in the urban centers with high densities of blacks are less likely to vote for the racially conservative candidate. Past research and the significance of the percent Urban X percent Black Density interaction suggests that because whites living in the urban areas possess less hostility toward blacks, they are less threatened by high black density.

As always, when conducting case studies, caution should be used in making generalizations. Also, it is recommended that an individual level analysis be conducted to better understand the type of racism employed by the electorate during the 1995 Louisiana gubernatorial race.

\section{LEGAL CASES}

Hays v. Louisiana. 1994. 862 F. supp. 119,126 (W.D. LA).

\section{NOTES}

This paper was originally presented at the annual meeting of the Southwestern Political Science Association, New Orleans, LA, April 1997. I wish to thank Richard Engstrom, Jonathan Knuckey, Susan Howell and Steve Van Winkle for their helpful suggestions during various stages of this project.

${ }^{1}$ Many of the problems of cross-level inference are based on the issue of model specification, i.e., the model specifications exploring these aggregate relationships must closely approximate the underlying individual relationship (Boyd and Iversen 1979; Hanushek, Jackson, and Kain 1974). However, according to Bartels and Brady, "In the meantime, the fact that no technique can compensate fully for the absence of relevant individuallevel data should not prevent analysts from utilizing the best available techniques for mitigating aggregation problems; nor should the ultimate intractability of ecological inference prevent us from continuing to strive for understanding in areas beyond the reach of ideally suitable data"' (1993, 130).

${ }^{2}$ Louisiana is unique compared to other states in that the Louisiana Department of Elections records both registration and turnout in nine cross-classified racial and partisan groupings. Further, the dependent variable employed in this analysis is highly correlated with both the vote for Duke in his 1990 senate race and the vote for Bush in the 1988 presidential 
race. Specifically, the correlation between the vote for Foster and the Duke vote was .63, compared to a correlation of .65 between the vote for Foster and the vote for Bush.

${ }^{3}$ The U.S. census does not collect this variable by race, therefore the total urban population is included. The use of this surrogate is consistent with the work of Giles and Buckner (1993).

${ }^{4}$ In keeping with Voss (1996), the model is weighted by the square root of white sign-in voters.

${ }^{5}$ Multicollinearity diagnostics were run and there were high correlations detected between the urban variable and the interaction term (urban X percent black density) of .85 and the interaction (urban $X$ percent black density) and the income variable of .79. While both the interaction and the urban variable proved to be statistically significant in Model B, this was not the case for the income variable. Hence, in an effort to test the independent impact of income, a separate model was run to include income as the sole independent variable. The results suggest that multicollinearity was not a problem. Said differently, the income variable was statistically insignificant at at the .60 level.

\section{REFERENCES}

Abramson, Mark. 1980. Urban Sociology. Englewood Cliffs, NJ: Prentice-Hall.

Alpert, Bruce. 1995. "For the Record." New Orleans Times Picaytne October 29:A1.

Bartels, Larry, and Henry Brady. 1993. "The State of Quantitative Political Methodology," in Ada Finifter, ed., Political Science: The State of the Discipline II. Washington, DC: American Political Science Association.

Boyd, Lawrence H., Jr., and Gudmund R. Iversen. 1979. Contextual Analysis: Concepts and Statistical Techniques. Belmont, CA: Wadsworth Publishing.

Carsey, Thomas. 1995. "The Contextual Effects of Race on White Vote Behavior: The 1989 New York City Mayoral Election." Journal of Politics 57:221-25.

Edsall, Thomas Byme, and Mary D. Edsall. 1991. Chain Reaction: The Impact of Race, Rights, and Taxes on American Politics. New York: Norton.
Erickson, Robert S., Gerald C. Wright, and John P. McIver. 1993. Statehouse Democracy: Public Opinion and Policy in the American States. New York: Cambridge University Press.

Giles, Michael W., and Melanie A. Buckner. 1993. "David Duke and Black Threat: An Old Hypothesis Revisited." Journal of Politics 55:702-13.

Giles, Michael W., and Melanie A. Buckner. 1995. "David Duke and the Electoral Politics of Racial Threat," in John C. Kuzenski, Charles S. Bullock III, and Ronald Keith Gaddie, eds., David Duke and the Politics of Race in the South. Nashville, TN: Vanderbilt University Press.

Giles, Michael W., and Melanie A. Buckner. 1996. "Comment." Journal of Politics 58:1171-80.

Giles, Michael W., and Arthur Evans. 1985. "External Threat, Perceived Threat and Group Identity." Social Science Quarterly 66:50-66.

Grace, Stephanie. 1995. "Voting Split on Race Line." New Orleans Times Picayrune November 10:A1.

Hanushek, Eric A., John E. Jackson, and John F. Kain. 1974. "Model Specification, Use of Aggregate Data and the Ecological Correlation Fallacy." Political Methodology 1:89-107.

Huckfeldt, Robert. 1986. Politics in Context: Assimilation and Conflict in Urban Neighborhoods. New York: Agathon Press.

Huckfeldt, Robert, and Carol Kohfeld. 1989. Race and the Decline of Class in American Politics. Urbana: University of Illinois Press.

Huckfeldt, Robert, and John Sprague. 1993. "Citizens, Contexts, and Politics," in Ada Finifter, ed., Political Science: The State of the Discipline II. Washington, DC: American Political Science Association.

Jeffries, Judson. 1995. "Douglas Wilder and the Continuing Significance of Race: An Analysis of the 1989 Virginia Gubernatorial Election." Journal of Political Science 23:87-111.

Key, V. O., Jr. 1949. Southern Politics in State and Nation. New York: Knopf.

Kinder, Donald, and Lynn M. Sanders. 1996. Divided by Color: Racial Politics and Democratic Ideals. Chicago: University of Chicago Press.

Kleppner, Paul. 1985. Chicago Divided: The Making of a Black Mayor. DeKalb, IL: Northern Illinois University Press. 
Kohfeld, Carol, and John Sprague. 1992. "Racial Context and Voting Behavior in One-Party Urban Political Systems." Presented at the NCGIA conference, Buffalo, NY.

Lazarsfeld, Paul F., Bernard Berelson, and Hazel Gaudet. 1968. The People's Choice. 3d. ed. New York: Columbia University Press.

Loewen, James. 1990. "Racial Bloc Voting and Political Mobilization in South Carolina." Review of Black Political Economy 19:23-37.

Ott, Brad. 1995. "Is Race the Issue?" Dialogue: Election Special 95. 2-4.

Przeworski, Adam. 1974. "Contextual Models of Political Behavior." Political Methodology 1:27-61.

Voss, D. Stephen. 1996. "Beyond Racial Threat: Failure of an Old Hypothesis in the New South." Journal of Politics 58:1156-70.

Wright, Gerald C., Jr. 1977. "Contextual Models of Electoral Behavior: The Southern Wallace Vote." American Political Science Review 71:497-508. 